\title{
Transboundary air mass transport from Kyzylkum desert
}

\author{
Karim Shukurov ${ }^{1, *}$, and Otto Chkhetiani ${ }^{1,2}$ \\ ${ }^{1}$ A. M. Obukhov Institute of Atmospheric Physics, Russian Academy of Sciences, 119017, Pyzhevsky per., 3, Moscow, Russia \\ ${ }^{2}$ Space Research Institute, Russian Academy of Sciences, 117997 Profsoyuznaya str., 84, Moscow, Russia
}

\begin{abstract}
The NOAA HYSPLIT_4 trajectory model and the NCEP/NCAR reanalysis have calculated the trajectories of air particles transport from the Kyzylkum desert (Central Asia). The average annual and seasonal (winter, spring, summer and autumn) was calculated for the probability of transport to different remote regions. The probability of transport only to the mixed layer was calculated. The peculiarities of large-scale atmospheric circulation are analyzed that facilitate the transport of air masses from the Kyzylkum desert to some regions of Russia and the south of Iran.
\end{abstract}

\section{Introduction}

The sand deserts of Central Asia release a large amount of fine and coarse aerosols to the atmosphere [1,2], which affects the quality of the habitat and the radiation characteristics of the atmosphere of the states of this region. The uplift of arid aerosols from the surface of the sandy desert occurs as a result of wind or vortex exposure [3-5]. In the latter case, removal of the aerosols can occur with a weak mean wind, under convective conditions $[4,6]$. As a result of thermal convection, the aerosols can spread to the entire mixing layer above the desert surface [7-9]. Thus, the uplift of arid aerosols from the surface of the desert can occur throughout the year, and not only during the dusty storm season.

Further, due to large-scale atmospheric circulation, the aerosols can be transported over very long distances [10]. In connection with this, it is of interest to study the average probability of air masses transport from the surface layer over the desert to remote regions. It is also interesting to identify the features of large-scale atmospheric circulation associated with the long-range transport. In this paper we analyze the transport of air masses from large sand deserts: Karakum (Turkmenistan), Kyzylkum (Uzbekistan), Taklamakan (China), Alashan (China), Saryesik-Atyrau (Kazakhstan), Mongolian Gobi (Mongolia), Dzungarian Desert (China), Tar (India), Registan (Afghanistan), Aralkum (Kazakhstan) and Ustyurt plateau (Kazakhstan). In this abstract, in view of the lack of space, the results of the study are shown only for the Kyzylkum desert.

\section{Data and methods}

In this work we use the technique [11], based on the analysis of an array of 10-day forward trajectories of air parcels (elementary air masses) calculated using the NOAA trajectory model HYSPLIT_4 [12] and
NCEP/NCAR reanalysis [13]. Air parcels started once every 24 hours in 1948-2017 at an altitude of $100 \mathrm{~m}$ above the nameless point $\left(43^{\circ} \mathrm{N}, 63^{\circ} \mathrm{E}\right)$ in the Kyzylkum desert near the border of Kazakhstan and Uzbekistan. The probability of transport of the air particle, $\mathrm{P}_{\mathrm{ij}}[\%]$, to the column of the atmosphere above the cell $[\mathrm{ij}]$ of $1^{\circ} \times 1^{\circ}$, is determined from the relation:

$$
P_{i j}=M_{i j} / N \text {, }
$$

where $\mathrm{M}_{\mathrm{ij}}$ is the number of unique trajectories that fall in the column above [ij], $\mathrm{N}$ is the number of all the trajectories that started. Also the transport probabilities for winter (December-January-February), spring (MarchApril-May), summer (June-July-August) and autumn (September-October-November) periods of 1948-2017 were calculated separately.

To determine the pattern of large-scale atmospheric circulation that favored the transport from the point in the Kyzylkum desert to the regions in Russia near Moscow $\left(55.7^{\circ} \mathrm{N}, 37.2^{\circ} \mathrm{E}\right)$, Sochi $\left(43.6^{\circ} \mathrm{N}, 39.7^{\circ} \mathrm{E}\right)$ and Novosibirsk $\left(55.0^{\circ} \mathrm{N}, 82.9^{\circ} \mathrm{E}\right)$ and in Iran near Zahedan $\left(29.5^{\circ} \mathrm{N}, 60.8^{\circ} \mathrm{E}\right)$ using the NOAA PSD resource https://www .esrl.noaa.gov/psd/data/composites the fields of sea level pressure anomalies (relative to the average for 1961-1980) were calculated for composites of days with transport from the desert to the specified regions. To display the fields, the Meteo-Info GIS software was used [14].

\section{Results}

In Fig. 1 shows the average transport probability (a) and the average transport (travel) time (b) of air particles from the Kyzykum desert (marked by a white circle) to various remote regions in 1948-2017.

* Corresponding author: karim.shukurov@,ifaran.ru 


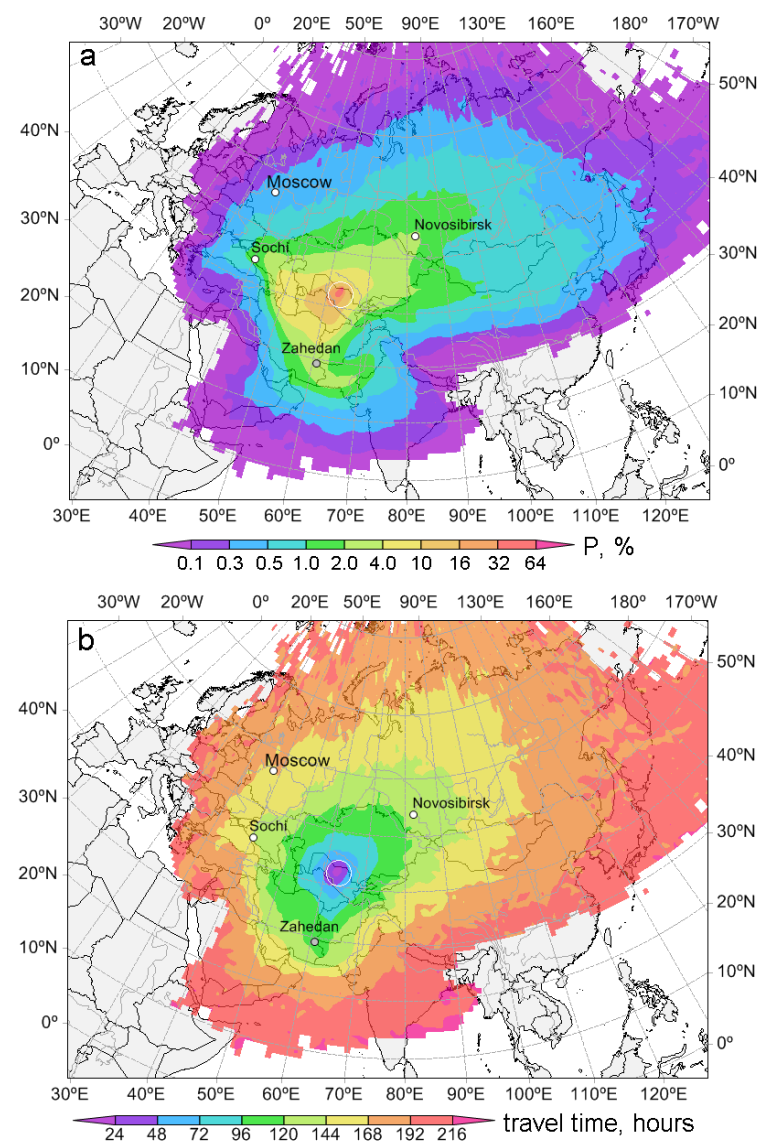

Fig. 1. The average transport probability (a) and the mean transport (travel) time (b) of air particles from the Kyzylkum desert (hereinafter marked by a white circle) in 1949-2017.

As can be seen from Fig. 1a air masses from the Kyzylkum desert are transported along three main directions: northeast toward the south of western Siberia (Novosibirsk), west-north-west, towards the Black Sea (Sochi) and south, towards the Indian Ocean (Zahedan). The transport to these three cities happens with a probability of $2-4 \%$. In other words, on average, for $1-2$ weeks per year, air from the deserts of Kyzylkum flows into the atmosphere near these cities.

The regions of the closest states to the desert, Uzbekistan and Turkmenistan are most affected by the desert (the transport of 60-120 days a year) (Fig. 1a). Northern Iran, almost the whole Caspian and the Caspian region of Kazakhstan are affected by the desert for 2-4 weeks per year. To Moscow, air masses arrive on average for only one day per year. The transport to Novosibirsk and Sochi lasts 5-6 days, to Zahedan 4-5 days (Fig. 1b). In Fig. 2 shows the probability of air particles from the Kyzylkum desert entering the mixed layer only [7]. In other words, this is an area where air particles from the Kyzylkum desert can reach the surface and have a direct effect on people.

As can be seen from Fig. 2 in Russia is the Southern and Federal District (SFD) and the North Caucasus Federal District (NCFD) and the south of western Siberia, where the air falls into mixed layer with a probability of $0.3-0.5 \%$.

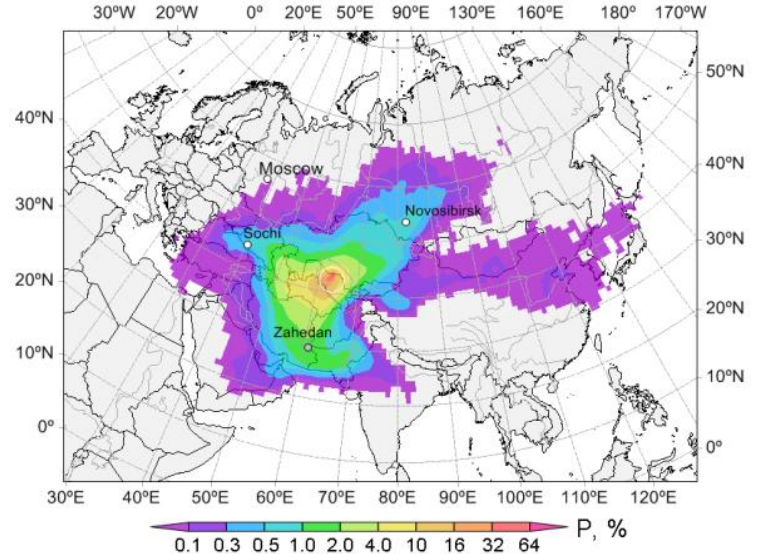

Fig. 2. The average probability of air parcel transport from the Kyzylkum desert to the mixed layer in 1948-2017.

For Zahedan, the probability is higher in four, and in the mixed layer in the Moscow region, air from the desert of Kyzylkum desert practically does not fall. As can be seen from Fig. 2 the greatest probability of air transport from Kyzylkum desert to the mixed layer, as well as for the entire atmosphere, is typical for Uzbekistan and Turkmenistan.

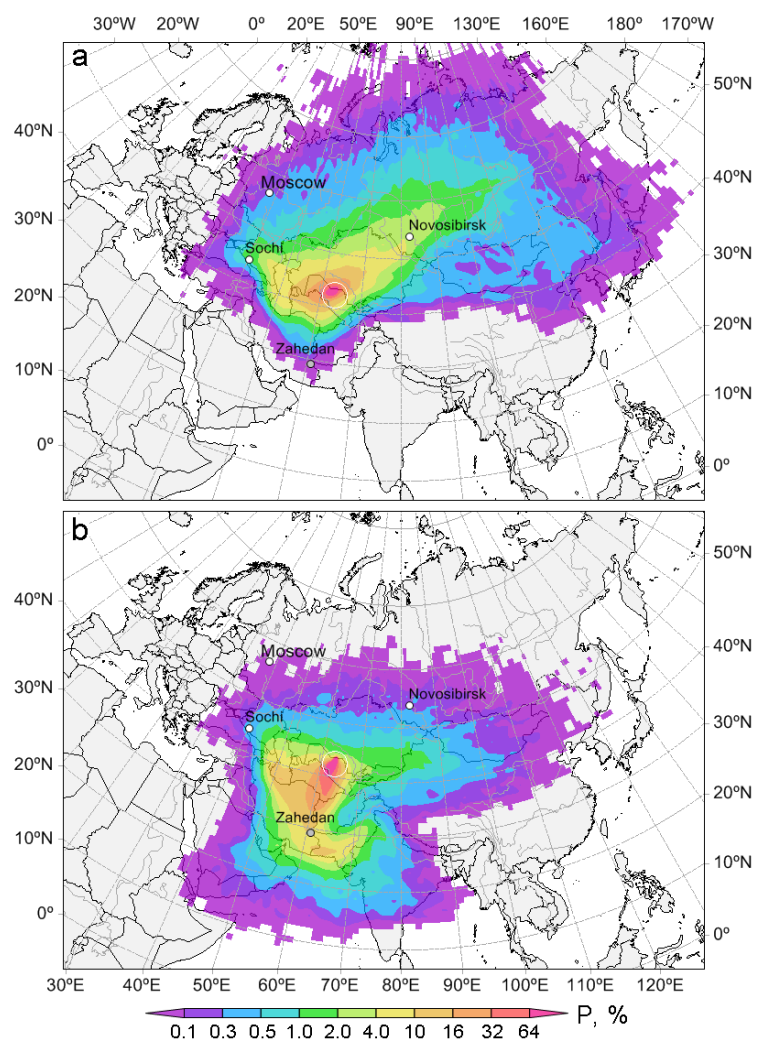

Fig. 3. The average probability of air parcels transport from the Kyzylkum desert in winter (a) and in summer (b) in 19482017.

The fields of the average probability of transport in winter (Fig. 3a) and in summer (Fig. 3b) vary considerably. In winter transport is predominant in the northeastern direction and practically absent in the southern direction (Fig. 3a). This field configuration is probably due to cyclonic activity. In summer, on the 
contrary, transport to the south dominates and there is almost no transport in the northern direction (Fig. 3b).

The transport probability fields for the transition seasons differ little (Fig. 4). Dust and sand storms in the region occur more often in spring and autumn, so the probability of arid aerosol transport to Russia during transitional seasons may be higher than in winter, despite the fact that the probability of air particles transport to Russia in spring (Fig. 4a) and in autumn (Fig. 4b ) is lower than in winter (Fig. 3a). In spring and autumn, except Turkmenistan and Uzbekistan, Kazakhstan and northern Iran are most vulnerable to air transport from the Kyzylkum desert.

In general, the probability of air transport from Kyzylkum desert to Russia and Kazakhstan is maximum in winter (Fig. 3a), for northwestern China in the spring (Fig. 4a) and in the autumn (Fig. 4b), for Iran, Afghanistan, Pakistan and India in summer (Fig. 3b), for Tajikistan, Kyrgyzstan and Mongolia in the spring (Fig. 4a). It is interesting that for Sochi the probability of the transport varies little during the year (Fig. 3 and 4).

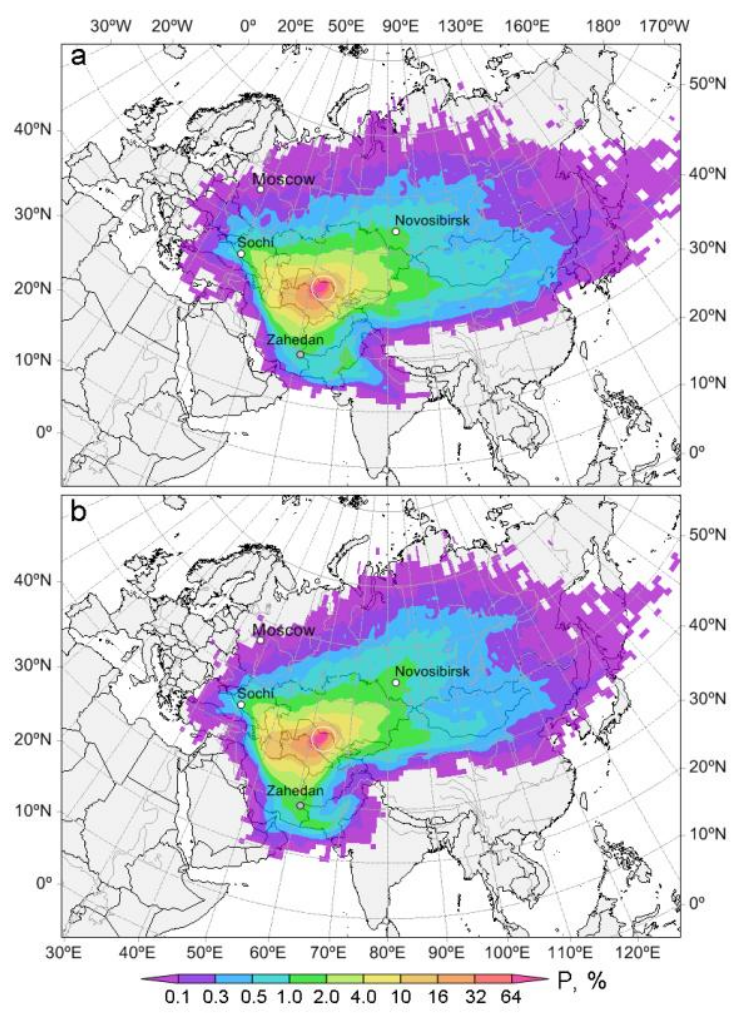

Fig. 4. The average probability of air parcels transport from the Kyzylkum desert in spring (a) and autumn (b) in 1948-2017.

The average probability of air transport from the Kyzylkum desert in 2000-2017 (Fig. 5b) is higher than in 1982-1999 (Fig. 5a) for Tajikistan, Kyrgyzstan, northwest China, northern Iran and Mongolia. In Russia in the XXI century the probability of the transport for the south of Siberia has decreased, for the SFD and the NCFD has practically not changed (Fig. 5). The transport of air particles to the Moscow region is favored by a large area of a positive pressure anomaly with a center over the southern Urals (Fig. 6a).

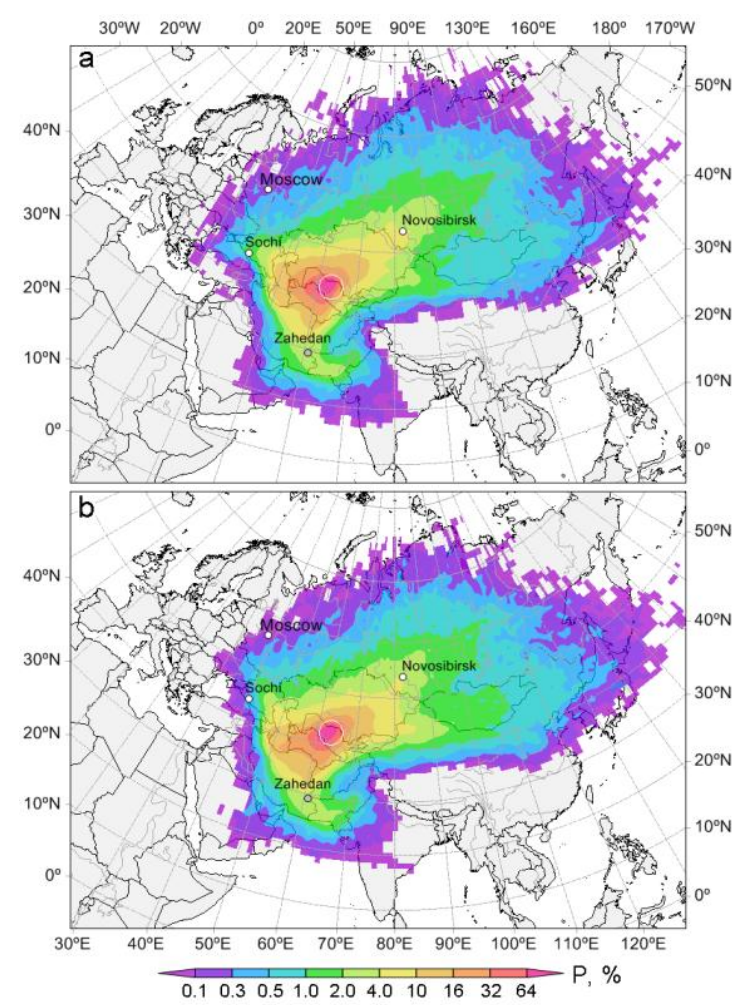

Fig. 5. The average probability of air parcels transport from the Kyzylkum desert in 1982-1999 (a) and 2000-2017 (b).

Apparently, the air masses from Kyzylkum desert are moving clockwise along the southwestern and western periphery of this anticyclonic anomaly to the Moscow region. The transport to the SFD and the NCFD occurs when this anticyclone increases so that its southwestern periphery reaches almost to the Black Sea.

The mechanism of air mass transport from the Kyzylkum desert to the south of western Siberia is on the contrary cyclonic (Fig. 6b). In this case, air masses from the desert move counter-clockwise along the southeastern periphery of the cyclone, whose center is moving to the east near the border of Russia and Kazakhstan. The transport to Kazakhstan is probably determined by the same cyclone. The transport to Tajikistan, Kyrgyzstan and Mongolia and to the northwest of China happens, apparently, when the trajectory of this cyclone shifts to the south. Judging by the probability of transport to different seasons (Fig. 3 and 4), these more southerly cyclones occur in spring and autumn, and in 2000-2017, more often than in 19821999 (Fig. 5).

The transport of air masses from the Kyzylkum desert to the south of Iran (Zahedan) occurs when the desert falls between the area of a positive anomaly centered on the Caspian lowland and the area of a negative pressure anomaly with a center over Mongolia, which extends to the west to Tajikistan and Kyrgyzstan and the northwestern regions China (Fig. 7). This feature of large-scale atmospheric circulation, which, apparently (Fig. 3b), is formed most often in the summer, promotes air transport in the meridional direction with a turn to the east near the Indian Ocean (Fig. 1a). 


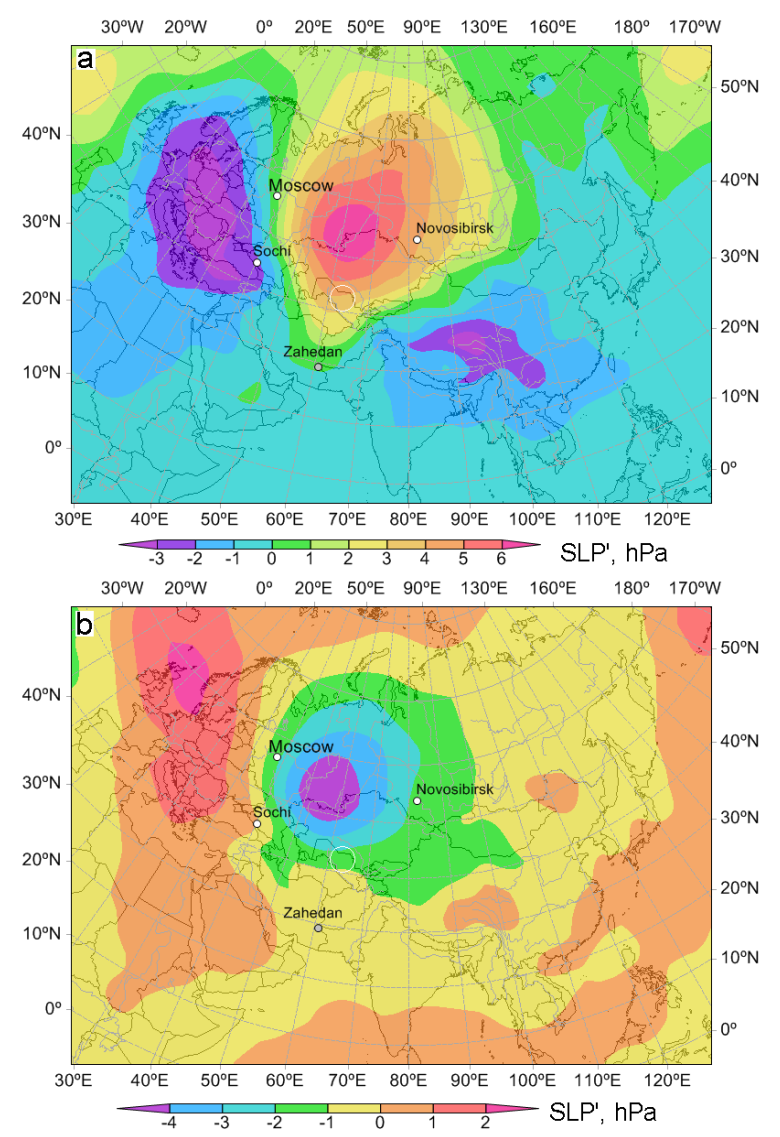

Fig. 6. Sea level pressure anomaly (relative to the average in 1961-1980) for composites of days with air transport from the Kyzylkum desert to Moscow (a) and south of Siberia (b) in 1948-2017.

It should be noted that in this case the difficult terrain with large mountain systems (the western Hindu Kush in Afghanistan, and the Nishapur mountains in Iran) should strongly influence the transport path, which, apparently, form a characteristic hook of transport towards the Indian Ocean (Fig. 1a).

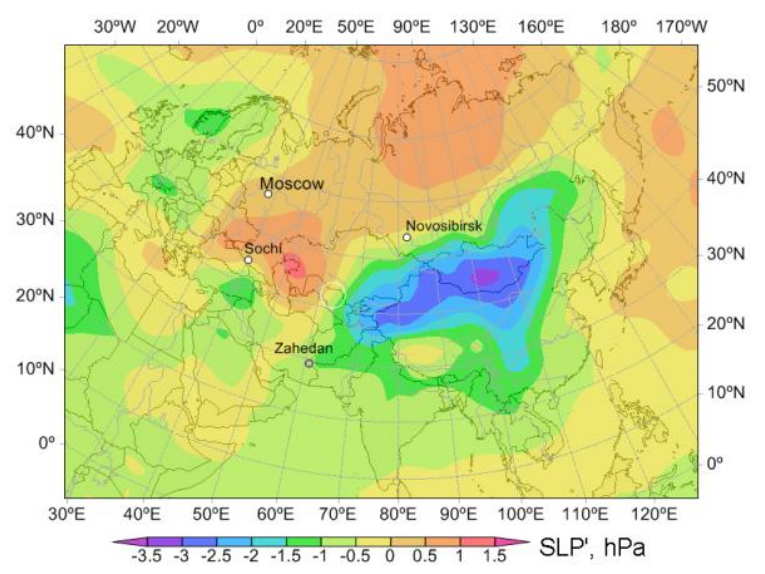

Fig. 7. The sea level pressure anomaly (relative to the average in 1961-1980) for a composite of days with air transport from the Kyzylkum desert to Zahedan (Iran) in 1948-2017.

\section{Conclusion}

On the example of the Kyzylkum desert using the trajectory analysis on the historical meteorological data (Reanalysis), it is shown that the transport of air masses (and, potentially, of arid aerosols) from one, relatively small, part of Central Asia affects (with different probability) onto the most of the countries of the region. Trajectory analysis on modeled meteorological data will allow us to estimate the dynamics of the air mass transport probability in the coming decades.

Analysis for the probability of air mass transport was carried out with support of RFBR grant RFBR-RGO No. 17-05-41121 and the Program of Fundamental Research No. 51 of the Presidium of the Russian Academy of Sciences.

\section{References}

1. T. Sternberg, M. Edwards, Int. J. Environ. Res. Public Health, 14, 1342 (2017)

2. A.S. Goudie, Environ. Int., 63, 101 (2014)

3. G.I. Gorchakov, B.M. Koprov, K.A. Shukurov, Izv. Atmos. Ocean. Phys., 38(SUPPL. 1), S138 (2002)

4. G.I. Gorchakov, B.M. Koprov, K.A. Shukurov, Izv. Atmos. Ocean. Phys., 39(5), 536 (2003)

5. G.I. Gorchakov, B.M. Koprov, K.A. Shukurov, Izv. Atmos. Ocean. Phys., 40(1), 679 (2004)

6. G.I. Gorchakov, K.A. Shukurov, Izv. Atmos. Ocean. Phys., 39(1), 75 (2003).

7. R. Stull, An introduction to boundary layer meteorology (Dordrecht/Boston/London: Kluwer Academic, 1988)
8. G.I. Gorchakov, P.O. Shishkov, V.M. Kopeikin et al., Atmos. Ocean. Opt., 11(10), 958 (1998) [in Russian]

9. Khrgian A.K., Physics of the Atmosphere (Leningrad, Gidrometeoizdat, 1969) [in Russian]

10. J.M. Creamean, J.R. Spackman, S.M. Davis, A.B. White, J. Geophys. Res. Atmos., 119 (2014)

11. K. A. Shukurov, O. G. Chkhetiani, Proc. SPIE, 10466, 104663V (2017)

12. R.R. Draxler, G.D. Hess, Aust. Meteorol. Mag., 47, 295 (1998)

13. R. Kistler, E. Kalnay, W. Collins et al., Bull. Am. Met. Soc., 82(2), 247 (2011)

14. Wang Y.Q. Meteorol. Appl., 21, 360 (2014) 